NBER WORKING PAPER SERIES

\title{
WHY IS ECONOMIC POLICY DIFFERENT IN NEW DEMOCRACIES? AFFECTING ATTITUDES ABOUT DEMOCRACY
}

\author{
Adi Brender \\ Allan Drazen \\ Working Paper 13457 \\ http://www.nber.org/papers/w13457 \\ NATIONAL BUREAU OF ECONOMIC RESEARCH \\ 1050 Massachusetts Avenue \\ Cambridge, MA 02138 \\ October 2007
}

We thank seminar participants at George Mason University, George Washington University, the University of Maryland, the 2007 SED meetings, the 2007 Collective Choice Conference, and the Spring 2007 Program meeting of the NBER Political Economy Program, especially our discussant Bard Harstad, as well as Peter Murrell and Razvan Vlaicu for very helpful comments. Amir Marchak, Lior Gallo and Sagie Dagan for superb research assistance. Drazen wishes to thank the National Science Foundation, grant SES-0418482, for financial support. Part of this paper was written while visiting the research department of the Bank of Israel, whose hospitality the second author gratefully acknowledges. The views expressed herein are those of the author(s) and do not necessarily reflect the views of the National Bureau of Economic Research.

(C) 2007 by Adi Brender and Allan Drazen. All rights reserved. Short sections of text, not to exceed two paragraphs, may be quoted without explicit permission provided that full credit, including $\odot$ notice, is given to the source. 
Why is Economic Policy Different in New Democracies? Affecting Attitudes About Democracy Adi Brender and Allan Drazen

NBER Working Paper No. 13457

October 2007

JEL No. D72,H30,P16

\begin{abstract}
$\underline{\text { ABSTRACT }}$
When democracy is new, it is often fragile and not fully consolidated. We investigate how the danger of a collapse of democracy may affect fiscal policy in new democracies in comparison to countries where democracy is older and often more established. We argue that the attitude of the citizenry towards democracy is important in preventing democratic collapse, and expenditures may therefore be used to convince them that "democracy works". We present a model focusing on the inference problem that citizens solve in forming their beliefs about the efficacy of democracy. Our approach differs from much of the literature that concentrates on policy directed towards anti-democratic elites, but our model can encompass that view and allows comparison of different apporoaches. We argue that the implications of the model are broadly consistent with the empirical patterns generally observed, including the existence of political budget cycles in new democracies not observed in established democracies.
\end{abstract}

Adi Brender

Research Department

Bank of Israel

Jerusalem 91007

ISRAEL

adib@bankisrael.gov.il

Allan Drazen

Department of Economics

University of Maryland

College Park, MD 20742

and NBER

drazen@econ.umd.edu 


\section{Introduction}

The 1990s saw a wave of democratization (Huntington's [1993] "third wave") as numerous countries moved from non-democratic to democratic regimes. These new democracies faced many challenges, among which were coping with the large structural changes that accompanied the change in political regime, as well as persuading the public that the economy functioned after these changes. Surely one of the largest challenges these new democracies faced was the possible fragility of the new regime and the need to consolidate democracy itself. "Established" democracies can (and do) take the stability of basic political structures for granted. Such is not the case in countries where democracy is a new (or even a "renewed") phenomenon and where the survival of the new political institutions is far from guaranteed.

Fragility or lack of consolidation of democracy refers to a situation in which some crucial political groups, including perhaps the general public, lack full commitment to the democratic process. This lack of widespread commitment to democracy makes it more vulnerable to anti-democratic elites. As Linz and Stepan (1996, p.5) put it, consolidation refers to "a political situation in which, in a phrase, democracy has become 'the only game in town.' Behaviorally, democracy becomes the only game in town when no significant political groups seriously attempt to overthrow the democratic regime ..."1 The fragility of democracy in countries that have recently made the transition to democracy raises an obvious question for economists: What economic policies can a government choose to try to help consolidate democracy?

A common view of the problem of democratic fragility is that the threat to democracy comes from anti-democratic elites — the army, groups such as the wealthy who benefitted most under the old regime, the "oligarchs". These are the groups who are seen as basically anti-democratic and who have the power to overthrow the new democratic regime. Focussing on the elites leads to a simple answer to the basic question posed at the end of the previous paragraph. Democratic consolidation requires economic policies that induce the anti-democratic elites not to overthrow democracy. That is, economic policy consistent with democracy must placate the elites, or, colloquially but not inaccurately, to "buy them off."

The clearest and best worked-out example of this approach is in the work of Acemoglu and Robinson, for example in Economic Origins of Dictatorship and Democracy (2005):

\footnotetext{
${ }^{1}$ An alternative definition is that of Schedler (1998, p. 103) that "the concept of a 'consolidated democracy' should describe a democratic regime that relevant observers expect to last well into the future-and nothing else." Since such expectations are likely to be formed on the basis of the probability that there will be successful challenges to the regime, this is consistent with our modeling of the probability of the survival of democracy.
} 
In building our theory of coups, we will emphasize the same economic and political incentives that featured prominently in understanding the creation of democracy. So far we have emphasized that in democratic societies the majority of citizens are able to alter policies in their favor and against the interests of elites. This makes the citizens pro-democratic while simultaneously giving the elite an incentive to oppose democracy. ... The same basic forces will also determine the incentives for coups. Since the elite prefer nondemocracy to democracy, they may, under certain circumstances, support a coup against democracy, which would lead to policies more favorable to themselves in the future.

The key assumption is that the citizenry is unambiguously in favor of democracy, the implication being that policy should focus on the elites. In studying the political economy of democratic consolidation, Acemoglu and Robinson then focus on the constraints put on fiscal policy by preventing the elites from trying to overthrow democracy.

In this paper we argue that while anti-democratic elites are clearly central to the understanding of coups, the assumption that the citizenry unambiguously supports democracy (and the implied focus almost exclusively on elites that this assumption leads to) misses some crucial issues in the process of democratic consolidation. In new democracies there is often large public skepticism of whether democracy "works", that is, whether it delivers the political and economic stability of the old regime. As we document in section 2.2, the data show significantly weaker support for democracy among the general population in new than in established democracies. Hence simply assuming that the citizenry supports democracy misses a key problem of democratic consolidation, namely the implications of public skepticism about democracy for its survival. Public discontent with democracy may strengthen anti-democratic elites, who may be unable to overthrow democracy in absence of public dissatisfaction of some sort.

A main challenge of policy is thus affecting public attitudes about democracy, especially at critical points of vulnerability of the democratic system, such as around elections. We further argue that looking at public perceptions of democracy as one of the key challenges of policy in new democracies may help us better understand some aspects of the evolution of fiscal policy in new democracies than would a sole focus on the elites. We are not saying that the arguments made by those who focus on elites in the consolidation process are incorrect or uninformative, but that this focus needs to be supplemented by consideration of the citizenry to better understand the policy implications of democratic fragility. More specifically, we argue that the incentives for an anti-democratic elite to stage a coup reflect both the expected benefit to the elite if the coup succeeds and their evaluation of the probability of success, which is negatively correlated with the general public's satisfaction with the functioning of democracy.

The plan of the paper is as follows. In the next section, we set out in greater detail the impor- 
tance of public attitudes towards democracy in the consolidation process. In section 3 we present a formal model concentrating on the importance of affecting public perceptions of democracy and derive some implications for both the timing and magnitude of fiscal policy actions in new democracies. Specifically, government spending and deficits will increase in times of democratic vulnerability and this increase may be quite substantial, depending on underlying parameter values. Section 4 presents evidence on fiscal policy consistent with the focus on affecting public attitudes. Among other things, we show that election years are points of democratic vulnerability, so that the democratic consolidation could imply a political budget cycle, but not because they help incumbents get re-elected (which other research of ours suggest they do not). We therefore suggest that problems of democratic consolidation may shed light on the empirical finding of Brender and Drazen (2005a) that political budget cycles are a phenomenon of new democracies but not established ones, but that increases in election-year deficits do not appear to help incumbents get re-elected. We also consider the composition of large election-year expenditure increases to argue that they are not directed solely at elites. Section 5 presents conclusions.

\section{Democratic Consolidation and Public Perception of Democracy}

\subsection{The importance of the citizenry in the survival of democracy}

Our argument on importance of the citizenry is that their attitudes towards the new democratic system may be crucial in determining whether democracy withstands anti-democratic pressure and survives. Though anti-democratic elites may have the interest in overthrowing democracy, their ability to do so depends on the attitudes of the citizenry towards democracy. Anti-democratic elites may be generally unable to successfully overthrow democracy without support from the citizenry (if only their lack of active opposition to reversion). Or, public unrest and dissatisfaction may provide the pretext for military intervention, supported by anti-democratic elites, to overthrow democracy and "restore order". The classic case in which lack of public commitment to democracy played a major role in its collapse is the Weimar Republic, but it is not the only example where public attitudes were important. ${ }^{2}$

This perhaps simple observation, when combined with the possibility that the masses may not be unambiguously convinced of the value of democracy, implies a quite significant change in how one should think about the use of economic policy to ensure the survival of democracy. It is no longer the

\footnotetext{
${ }^{2}$ Bermeo (1993) presents a large number of case studies, both where public support was a major factor and where it was not.
} 
case that policy should be aimed simply at "buying off" the elites. If some degree of support from citizens is crucial to the overthrow of democracy, policy must also be aimed at ensuring their support for democracy, thus making a coup and a democratic collapse less likely or perhaps impossible.

This approach thus forces a reconsideration of the assumption that the interest of the masses is unambiguously in favor of democracy. Conditional (rather than unconditional) support on the part of the citizenry is consistent with the focus in the literature on the importance of public attitudes about the efficacy of democracy. ${ }^{3}$ Efficacy clearly has economic dimensions and if citizens do not believe that democracy is able to solve economic problems, this may be fatal for democracy. In new democracies the efficiency of the new political system, and not just its legitimacy, becomes a crucial issue. As Linz and Stepan (p. 80) put it

The key question for the democracies is whether their citizens believe that, in the circumstances, the democratic government is doing a credible job in trying to overcome economic problems. It is important to stress that the political economy of legitimacy will produce severe and perhaps insoluble challenges to democratic consolidation in those cases where the democratic system itself is judged to be incapable of producing a program to overcome the economic crisis.

While belief in efficacy by the citizens is crucial, beliefs can change over time. In summarizing the experience of the new democracies of Southern Europe, Linz and Stepan write (p. 144)

... the overwhelming majority of consolidated democracies did not actually begin their transition to democracy with a majority of members of the polity or even many of the key agents of the transition being either convinced democrats or citizens who rejected everything about the past regime. Rather, a democratic majority emerges when elites and ordinary citizens alike begin to evaluate, for the societal problems they then face and the overall world within which they then live, that democratic procedures of conflict regulation are better or less dangerous than any other form of governance. Thus, for many key elites democratic behavior emerges before democratic attitudes because elites may make the calculation that breaking the democratic rules of the game - whether they like them or not - will not yield a positive outcome for their interests. Democracy becomes the "only game in town" partly by belief and partly by elite calculation of the cost of compliance versus the cost of mobilization for other governing alternatives. (italics ours)

Note further that the transition to democracy is often associated with large structural changes in the economy. This was particularly noticeable in the formerly socialist economies of Eastern Europe but also in Southern Europe and in some Latin American countries. The twin transitions may thus imply an especially great need to show that the economic system functions under the new arrangements. In order to concentrate on the fiscal implications of showing that democracy works, in our modeling we abstract away from any direct effect of the economic transition on fiscal policy, though large structural changes will be a key reason for the difficulty in drawing inferences about how well the system functions. (See section 2.3 below.)

\footnotetext{
${ }^{3}$ See, for example, the wide-ranging survey of Linz and Stepan (1996).
} 


\subsection{Evidence on public attitudes}

Recent data from the World Values Survey (Inglehart, 2004) support the view that ordinary citizens in new democracies are not unconditional supporters of democracy. We tabulated differences in the responses between new and old democracies (as defined in Brender and Drazen [2005a]) and after controlling for characteristics such as per-capita income and the age-structure of the population, investigated what significant differences remained in answers to the survey questions. These results from equations based on the mean values for each country are summarized in Table 1 . We note three differences between the responses in new and old democracies that may help explain policy differences between new and established democracies. In new democracies: 1) democracy is less consolidated; 2) people appear to be more tolerant of manipulation; and, 3) people care more about good economic performance. (This last difference is consistent with the empirical work in Brender and Drazen [2005b] on the stronger effect of economic growth on re-election probabilities in new versus old democracies.)

In this paper we focus on the first difference, but the second and especially the third suggest how policy may be used to consolidate democracy. Other studies find that the survival of democracy is quite sensitive to economic performance. Przeworski, et al.(2000) find empirically that better growth performance makes a democracy more likely to survive, while poor economic performance makes both presidential and parliamentary systems more vulnerable. Bernhard, Reenock, and Nordstrom, (2003) find this to be true especially prior to the third legislative election. Many other authors make similar observations (see, for example, Linz and Stepan [1978] or Remmer [1996].) ${ }^{4}$

The findings in Table 1 are confirmed in when we estimate similar equations at the individual level, looking for differences between individuals who live in new and old democracies (Table 1A). In addition to country characteristics, we also control in these equations for various individual characteristics such as age, gender, the individual's income level, and religion.

\section{[Put Tables 1 and 1A Here]}

Individual level data also confirm the widely held presumption that within new democracies, it is older citizens who express greater doubts about the value of democracy, as summarized in Figure 1, where we show attitudes about democracy in new democracies relative to established ones across age groups.

\section{[Put Figure 1 Here]}

\footnotetext{
${ }^{4}$ It is often argued that the survival of authoritarian regimes is also sensitive, perhaps even more so, to perceptions of their ability to deliver good economic performance. This observation in no way invalidates the sensitivity of democratic regimes to economic performance, our subject of interest.
} 


\subsection{Information about policies}

We also note that there was no significant difference between new and old democracies in the World Values Survey in responses on people's exposure to politics or news at the country level, as seen in Table 1 (though there may be less "fiscal content" in the news). In fact, the results at the individual level in Table 1A suggest that people in new democracies tend to follow politics in the media more than those in old ones. Similar exposure to politics and news does not however mean that citizens have similar quality information about how well the economy works. This distinction is crucial to our modeling of policy in new versus established democracies. ${ }^{5}$

More specifically, we argue that in new democracies, citizens have less information about fiscal outcomes, as well as less understanding of the political process generating fiscal policy. This would reflect experience with the electoral process by voters, the establishment of the institutions that would collect and provide the relevant data, and experience by media in disseminating and analyzing this information. The combination of limited experience with democracy and limited fiscal information make it more difficult for citizens in new democracies to see through fiscal policies meant to convince them that democracy is working.

The difficulty in analyzing economic and fiscal developments in new democracies is not limited to less availability of information. Due to the substantial structural changes in the economy which often accompany the transition to democracy, it is likely that the interpretation of observable data becomes more complicated. To examine the possible effect on fiscal policy of such changes, we considered changes in the composition of government expenditures in a panel of 70 countries during the period 1970-2004. We found that changes in the composition of government expenditures in new democracies were 60-65 percent larger than in established ones. ${ }^{6}$ Consequently, when citizens in new democracies observe improvements in the public services they receive - or higher transfer payments it is more difficult for them to infer whether these reflect a more efficient allocation of public resources (as part of the transition process) or fiscal manipulation via deficit spending. ${ }^{7}$

Information problems are so important because fragility alone is not sufficient to explain the use of fiscal policy to affect attitudes about democracy; it is the combination of fragility and imperfect

\footnotetext{
${ }^{5}$ Brender (2003) shows that the development of information sources about fiscal performance and the means to deliver them to the public had a substantial effect on the response of citizens to such information.

${ }^{6}$ We decomposed the GFS data on central government spending to 9 categories (by function) and created an index of the annual change of this composition by summing the absolute values of the changes in the shares of all the categories and dividing the total by 2. Based on 988 observations (of which 349 were from new democracies) we found that the index for new democracies is 6.6 and for established democracies 4.0. Using 12 expenditure categories (with 836 observations) the average change among new democracies was 7.5 and among the established ones 4.5.

${ }^{7}$ The difficulty in making inferences from observable fiscal data underlies many models of trying to influnce voters, beginnig with Rogoff and Sibert (1988) and Rogoff (1990).
} 
inference about fiscal policy that is key to why policy in new democracies is different. Newness implies incomplete information about how the economic system will function under democracy (and how democracy itself works). Hence, expenditures to strengthen the public's perception of a well-

functioning system - for example, paying salaries to government workers on time - will not be so easily identified as manipulation when citizens have limited experience with democracy (and "electionyear" economics), as well as facing large structural changes . As voters gain more experience with the democratic system and as information improves, using fiscal policy to "grease the wheels" of the economic system may be increasingly less effective in affecting public perceptions, and hence may be less likely to occur. That is, an old democracy may be fragile, but the public's experience means that fiscal manipulation will be seen as such and hence be ineffective.

The distinction between newness and fragility of democracy leads to another distinction, namely between use of fiscal policy in critical periods to try to show that the system works and genuine reform. The general view is that new democracies can survive social strife and economic instability for some years, but are likely to break down in the medium to long run unless they can address problems of poverty and inequality through reforms that provide the basis for sustainable growth. Our focus on the role of fiscal policy in reducing the vulnerability of democracy to breakdown should not be read as contradicting this view. Quite the contrary. Our argument is applied to new democracies, rather than any fragile democracy, precisely because we believe that such policies can only be effective when the democratic regime is young, after which fiscal manipulation will be seen as such and hence will not reduce (and may well increase) the vulnerability of democracy to breakdown. In this paper our motivation is positive, not normative, in exploring the implications of newness for fiscal policy. Expenditures to show the system works are not a substitute for true reform; they may be a temporary attempt to bridge a particularly crucial breakpoint of democracy.

\section{A Framework of Analysis}

We now turn to modeling the relation between fiscal policy and fragility of democracy. We ask how fiscal policy may be different in new than established democracies because democracy is not fully consolidated when it is only recently adopted. We focus on the effect of economic policy on inducing support for democracy via the probability that citizens assign to democracy being superior to nondemocracy, rather than on the utility they associate with one system or the other. That is, we view the key problem that citizens face as an inference problem of deciding whether democracy "works", depending on their observation of economic outcomes. Government expenditures can there- 
fore increase public support for democracy primarily by inducing citizen's to increase the probability they assign to democracy "working". This does not mean that citizens have not formed beliefs about democracy but that, given their attitudes, their willingness to support (defend) democracy would depend on their perception of its ability to deliver a functioning economy in the particular country.

We present a simple two-period example (embedded in a multi-period model) in which the two periods differ in the vulnerability of democracy to collapse. To make the effect of democratic fragility on fiscal policy quite sharp, for the bulk of the paper we assume that spending on items that will affect public perception of democracy is the only type of expenditure the government has. While such assumption is clearly unrealistic, it means that any difference in fiscal policy that the model predicts for new versus established democracies is due to the government's attempt to consolidate democracy. In section 3.4.2 we add another type of government spending to help illustrate the determinants of the magnitude of expenditures that affect public attitudes.

We assume that in established democracies, fiscal policy is fully observed, consistent with the view that information about fiscal policy is better once citizens (and the media) have more experience with democracy and there is greater transparency in policymaking. In contrast, consistent with the view that citizens in new democracies lack experience with democracy and have imperfect information about fiscal policy, we assume that citizens in a new democracy do not observe spending on items that will affect public perception of democracy, which we denote $h_{t}$. (Alternatively, citizens cannot infer whether $h_{t}$ is substituting for other types of spending or is financed by a deficit, or cannot infer the effect of $h_{t}$ on outcomes.) We do however allow that they assign some probability that the government is spending to affect citizen perceptions, that is, that $h_{t}>0$.

The sequence of events in a period is as follows. In each period, the government chooses $h_{t}$, after which an event $Z_{t}$ is realized. The probability of a good outcome of the event is increasing in $h_{t}$. On the basis of the outcome of this event, citizens update their beliefs about the efficacy of democracy, as summarized by a common posterior probability $P_{t}$ that democracy is generally "good" for economic outcomes (democracy "works"). Key to the updating is the belief of citizens that even if democracy is not good for economic outcomes in general (and there is no government manipulation via $h_{t}$ ), a good outcome may be observed (and conversely) so that the outcome of a given event is not conclusive on the efficacy of democracy. Given the distribution of utilities associated with their perceptions of democracy and autocracy in the population, the probability $P_{t}$ induces support for democracy by a fraction $\phi_{t}$ of the citizenry, where $\phi_{t}$ is increasing in $P_{t}$. Based on $\phi_{t}$, anti-democratic elites decide whether to stage a coup, where the likelihood of a coup succeeding is decreasing in $\phi_{t}$ (which will 
imply that the probability $\sigma_{t}$ of survival of democracy is increasing in $\phi$.) If democracy survives, a similar set of decisions is made in the second period. If not, the economy becomes a non-democracy in the second period.

\subsection{Citizens' Perceptions of Democracy}

\subsubsection{Individual utility}

We assume that citizens differ from one another in the utility they assign to different regimes: democracy believed to be superior to nondemocracy for economic outcomes; democracy believed to be inferior to the (previous) non-democratic regime for economic outcomes; and, nondemocracy.

A citizen $i$ 's expected utility in any period $t$ may be written

$$
U^{i}(\cdot) \equiv \sigma_{t}\left[P_{t} V_{t}^{G i}+\left(1-P_{t}\right) V_{t}^{B i}\right]+(1-\sigma) V_{t}^{A i}
$$

where $\sigma_{t}$ is the probability that democracy survives in period $t, V_{t}^{G i}$ is $i$ 's expected welfare under democracy in $t$ if he believes democracy "works", $V_{t}^{B i}$ is his expected welfare under democracy in $t$ if he believes democracy doesn't "work", $V_{t}^{A i}$ is his expected welfare under autocracy (non-democracy), and $P_{t}$ is the probability that citizens assign to democracy "working" based on outcomes in $t$.

Since our focus is on affecting beliefs about whether democracy is good for outcomes (rather than utility conditional on a given belief), we assume for simplicity that $V_{t}^{G i}$ and $V_{t}^{B i}$ are given and cannot be affected by government policy. The dependence of $\sigma$ and $P$ on $h$ will be discussed below. For simplicity the discount rate is assumed to equal 0.

\subsubsection{The individual decision rule}

A citizen's only decision is whether or not to support democracy. Non-support may take many forms: not voting; demonstrating against democracy or the government; not opposing coup attempts, or even general civil unrest induced by skepticism about the political and economic regime.

Citizen $i$ supports democracy in $t$ if and only if

$$
P_{t} V_{t}^{G i}+\left(1-P_{t}\right) V_{t}^{B i} \geq V_{t}^{A i}
$$

The crucial, but reasonable assumption is that $V_{t}^{G i}>V_{t}^{A i}>V_{t}^{B i}$ for at least some citizens $i$. (If $V^{B i} \geq V^{A i}$, then a citizen supports democracy for sure for any value of $P$. If this holds for all $i$, then all citizen support democracy no matter what is inferred about $P$, so that democracy is fully consolidated.) 
Equation (2) with equality defines a critical value $\hat{P}_{i}$ for citizen $i$ such that he supports democracy in $t$ if

$$
P_{t} \geq \hat{P}_{t}^{i} \equiv \frac{V_{t}^{A i}-V_{t}^{B i}}{V_{t}^{G i}-V_{t}^{B i}}
$$

and does not support if $P_{t}<\hat{P}_{t}^{i}$. We note the possibility that the values of $V_{t}^{G i}, V_{t}^{A i}$, and $V_{t}^{B i}$ may evolve over time as people become more experienced with democracy. Specifically if $V_{t}^{G i}$ is rising as a democracy matures while $V_{t}^{A i}$ is falling for all individuals, then the citizen-specific critical value $\hat{P}_{t}^{i}$ will fall over time, so that support for democracy will rise over time for any inferred $P_{t}$. For simplicity of exposition, we do not pursue this idea in the current paper and take $V^{G i}, V^{A i}$, and $V^{B i}$, and hence $\hat{P}^{i}$ as time-invariant. ${ }^{8}$

\subsubsection{The basic inference problem for $P$}

Since citizens update their prior on the unobserved efficacy of democracy on the basis of observed economic outcomes, a natural framework is to use is Bayesian updating. Suppose that individuals form the posterior $P_{t}$ that democracy "works" ("salaries and allowances are paid", "electricity gets delivered", etc.) using Bayes' rule on the basis of observed economic performance and their prior belief. In an unconsolidated democracy, where the prior $P_{t-1}<1$, observed outcomes may lead to an updating of beliefs. We consider a simple " $2 \times 2$ " example, but this can be easily extended to multiple outcomes or levels of democracy.

Consider an "event" $Z_{t}$ that can have two outcomes: a "good" outcome $Z_{t}=S$ and a "bad" outcome $Z_{t}=X$ where we interpret "events" or "outcomes" not simply as general macroeconomic outcomes, but as specific events, such as government meeting its financial obligations. As indicated above, a good outcome may be observed even if democracy is not generally good for outcomes. Hence, let $\gamma_{t}=\operatorname{Pr}\left(Z_{t}=S \mid\right.$ democracy "works") and $\beta_{t}=\operatorname{Pr}\left(Z_{t}=S \mid\right.$ democracy doesn't "work" $)$, where $1>\gamma>\beta>0$. Suppose that the true probability of observing a good outcome is $\delta$ where $\gamma \geq \delta>\beta .^{9}$

To characterize the results of the representative citizen's inference problem, consider first two polar cases for individual knowledge of the process generating outcomes. The first is that the government is

\footnotetext{
${ }^{8}$ In general, one may expect that support for democracy will increase over time, if for no other reason than a demographic change so that as older citizens used to the previous non-democratic regime die, a larger fraction of individuals support democracy. This is consistent with the findings reported in Figure 1.

${ }^{9}$ It is a less than fully settled question on whether democracy produces better economic outcomes than nondemocracies (for example, on relative growth performance of democracies and nondemocracies, as in Tavares and Wacziarg [2001]) However, our conceptual results do not depend on what in fact is the probability of a "good" outcome under democracy as long as in a new democracy: 1) citizens are not convinced of the efficacy of democracy and hence face an inference problem as posited; and, 2) the government has some ability to manipulate outcomes.
} 
not manipulating outcomes. Denote by $P_{t}\left(\cdot \mid Z_{t} ; v\right)$ the posterior $P_{t}$ that democracy is good conditional on the observed outcome $Z_{t}$ and a probability $v$ that outcomes are manipulated. The posterior that democracy is good for outcomes when citizens place 0 probability on manipulation and observe $Z_{t}$ may then be written:

$$
\begin{aligned}
P_{t}\left(\cdot \mid Z_{t}=S ; 0\right) & =\frac{P_{t-1} \gamma_{t}}{P_{t-1} \gamma_{t}+\left(1-P_{t-1}\right) \beta_{t}} \\
P_{t}\left(\cdot \mid Z_{t}=X ; 0\right) & =\frac{P_{t-1}\left(1-\gamma_{t}\right)}{P_{t-1}\left(1-\gamma_{t}\right)+\left(1-P_{t-1}\right)\left(1-\beta_{t}\right)}
\end{aligned}
$$

where $P_{t-1}$ is the probability assigned to democracy being good for outcomes prior to observing the event $S$ or $X$.

In the second polar case, individuals are certain that outcomes are (successfully) manipulated by the government, modeled by assuming that individuals believe that outcome $S$ occurs with probability $\mu \geq \delta$ (and $X$ occurs with probability $1-\mu$ ) independent of whether democracy is actually good or bad for outcomes. (We return to government behavior in manipulating outcomes in section 3.3.2). In this case Bayesian updating in (4) gives the obvious result that the posterior is equal to the prior $P_{t-1}$ independent of the realization of the random variable $Z_{t}$, that is, $P_{t}\left(\cdot \mid Z_{t}=S ; 1\right)=P_{t}\left(\cdot \mid Z_{t}=X ; 1\right)=$ $P_{t-1}$.

When a democracy is new, so that individuals have less knowledge and understanding of the workings of government, we assume that $h_{t}$ is imperfectly observed. We represent the degree of knowledge of fiscal policy in a stylized way by assuming that with probability $\nu_{t}$ (that is, the probability that individuals assign to fiscal policy being manipulated) the second case is relevant and the posterior is simply the prior $P_{t-1}$, and with probability $1-\nu_{t}$ the first case is relevant, so that the posteriors are given by (4). The posterior is then the weighted sum of the two cases, namely

$$
\begin{aligned}
P_{t}\left(\cdot \mid Z_{t}=S ; \nu\right) & =\frac{\left(1-\nu_{t}+\nu_{t} P_{t-1}\right) P_{t-1} \gamma_{t}+\nu_{t} P_{t-1}\left(1-P_{t-1}\right) \beta_{t}}{P_{t-1} \gamma_{t}+\left(1-P_{t-1}\right) \beta_{t}} \\
P_{t}\left(\cdot \mid Z_{t}=X ; \nu\right) & =\frac{\left(1-\nu_{t}+\nu_{t} P_{t-1}\right) P_{t-1}\left(1-\gamma_{t}\right)+\nu_{t} P_{t-1}\left(1-P_{t-1}\right)\left(1-\beta_{t}\right)}{P_{t-1}\left(1-\gamma_{t}\right)+\left(1-P_{t-1}\right)\left(1-\beta_{t}\right)}
\end{aligned}
$$

From these equations it is clear that the posterior $P_{t}\left(\cdot \mid Z_{t}=S ; \nu\right)$ is falling in $\nu$, while $P_{t}\left(\cdot \mid Z_{t}=X ; \nu\right)$ is rising in $\nu$, so that as information gets better, difference between posteriors conditional $Z_{t}=S$ and $Z_{t}=X$ narrows.

Equations (4) have a number of basic implications. In an unconsolidated democracy $\left(P_{t-1}<1\right)$ a bad outcome will lower the posterior probability $P_{t}$ that citizens assign to democracy being good 
for outcomes, while a good outcome will have the opposite effect. The more individuals are aware that manipulation may be taking place (the larger is $\nu$ ), the smaller is this effect. In an established democracy where $P_{t-1}=1$, outcomes have no effect on perceptions of or support for democracy. This is the essence of the individual inference problem which will play a key role in determining government's choice of fiscal policy in a new democracy.

\subsubsection{Public support for democracy}

The common value $P_{t}$ can then be translated into support for democracy in the population as a whole. The distribution of values of $V^{G i}, V^{B i}$, and $V^{A i}$ in the population induces a distribution of $\hat{P}^{i}$ via equation (3). Denote the CDF of $\hat{P}^{i}$ by $F\left(\hat{P}^{i}\right)$. For future use we denote by $V^{G}, V^{B}$, and $V^{A}$ as population averages of the individual utility indicators $V^{G i}, V^{B i}$, and $V^{A i}$.

The fraction of citizens $\phi_{t}$ who support democracy at $t$ for a value $P_{t}$ is then simply

$$
\phi_{t} \equiv F\left(P_{t}\right)
$$

that is, the fraction of citizens with $\hat{P}^{i} \leq P_{t}$. In a consolidated democracy, where $P_{t}=1$, all citizens have $\hat{P}^{i} \leq P_{t}$ and $\phi_{t}=1$. The key observation here is that in an unconsolidated democracy with $P_{t}<1$, the higher is $P_{t}$ the greater is the fraction $\phi_{t}$ of citizens who support democracy.

\subsection{Survival of Democracy}

How is citizen support of democracy connected to democratic survival? It seems natural to argue that the probability that democracy survives at any point in time, call it $\sigma_{t}$, is increasing in the fraction $\phi$ of citizens who support democracy. It would be nonsensical to argue that the chances of democratic survival are decreasing in $\phi$. Hence, the essential point is that the probability that democracy survives, that is, that there is not a reversion to autocracy, is not independent of public support for democracy. This may seem obvious as well, though focussing solely on anti-democratic elites in discussing problems of democratic consolidation implicitly assumes that public support for democracy is not an important factor.

\subsubsection{Anti-Democratic Elites}

To make the argument more specific, we consider an antidemocratic elite, which will attempt to overthrow democracy if it believes such an attempt is in its interest. What stops the elite from attempting to overthrow democracy is the perception of low probability of success (and high cost of failure), where probability of success is inversely related to $\phi$, the fraction of the public who support 
democracy. ${ }^{10}$ Hence, democracy survives if the elite finds it preferable not to attempt to overthrow it when comparing the expected costs and benefits of trying to overthrow it, or when a attempted coup is unsuccessful.

More formally, consider the decision problem of the elites. Denote by $\xi_{t}$ the probability of successful overthrow in period $t$, where

$$
\xi_{t}=\xi\left(\phi_{t}, t\right)
$$

where $\frac{\partial \xi}{\partial \phi}<0$. The time argument in the function $\xi\left(\phi_{t}, t\right)$ reflects our argument that the threat to democracy for a given value of $\phi$, need not be identical at all points in time. This is a simple representation of our point above that the vulnerability of democracy will vary over time.

The elite will not attempt a coup at $t$ if and only if

$$
W^{D} \geq \xi\left(\phi_{t}, t\right) W^{A}+\left(1-\xi\left(\phi_{t}, t\right)\right) W^{F C}
$$

where $W^{D}$ is the welfare of the elite under democracy, $W^{A}$ is their welfare under nondemocracy ("autocracy"), and $W^{F C}$ is their welfare under a failed coup. We assume that $W^{A}>W^{D}>W^{F C}$. If (8) is satisfied, democracy survives in period $t$ with probability 1 . If it is not satisfied, the antidemocratic elite attempt a coup and democracy survives with probability $1-\xi\left(\phi_{t}, t\right)$. We assume that $\lim _{\phi \rightarrow 1} \xi(\cdot, t)=\underline{\xi}<\frac{W^{D}-W^{F C}}{W^{A}-W^{F C}}$, so that when $\phi_{t}=1$, no coup is attempted.

The probability $\sigma_{t}$ that democracy survives in period $t$ is then given by

$$
\begin{array}{cc}
\sigma\left(\phi_{t}, t\right)=1 & \text { if } \phi_{t} \geq \hat{\phi}_{t} \\
\sigma\left(\phi_{t}, t\right)=1-\xi\left(\phi_{t}, t\right) & \text { if } \quad \phi_{t}<\hat{\phi}_{t}
\end{array}
$$

where $\hat{\phi}_{t} \equiv \xi^{(-1)}\left(\frac{W^{D}-W^{F C}}{W^{A}-W^{F C}}, t\right)<1$. (That is, for $\phi_{t} \geq \hat{\phi}_{t}$, no coup will be attempted.) In a consolidated democracy in which citizens are convinced that democracy is "good" (that is, $P_{t-1}=P_{t}=1$ ), this belief implies that $\phi_{t}=1$. Hence, $\xi=\underline{\xi}$, no coup will be attempted, and $\sigma_{t} \equiv 1$. In a new democracy the value of $\sigma_{t}$ will depend on the realized value of $\phi_{t}$ which in turn depends on $P_{t}$ and government policy affecting attitudes.

Condition (8) and the implied survival probabilities (9) may be used to summarize different

\footnotetext{
${ }^{10}$ This argument may be made in any democracy, new or old, fragile or consolidated. That is, in a consolidated democracy, anti-democratic elements may have the desire to substitute a democratic system with an alternative that favors them, but realize that public support for democracy is sufficiently strong, that any attempt to do so is fruitless and hence is not attempted. This is fully consistent with Linz and Stepan's 'only game in town' definition given in the introduction,
} 
approaches to studying consolidation of democracy that our model can represent. In our approach, we take the $W^{J}(J=D, A, F C)$ and the function $\xi(\cdot, t)$ as given and consider policies that raise $\phi_{t}$, thus raising $\sigma\left(\phi_{t}, t\right)$. A focus on "buying off" elites, as in the work of Acemoglu and Robinson discussed above, could be thought of as taking $\phi_{t}$ as given and considering policies that raise $W^{D}$. A third focus could be on institutional change that would shift the function $\xi(\cdot, t)$ by making coups harder to mount, for example, greater civilian control of the army. It could also represent the evolution of political institutions that lowers the ability of elites to achieve their aims. Note further that by introducing dependence of $\xi$ on $\phi$, our model can also consider the evolution of the probability of democratic survival $\sigma$ due to demographic changes that change $\phi_{t}$ over time (such as steady increase in the fraction of the population with no experience with the old regime), distinct from a changed position of elites or in institutions.

The possibility of "nesting" different approaches to consolidation in our model has a number of advantages. It makes clear that our approach focussing on affecting public attitudes towards democracy is complementary to approaches that focus on placating the elites or on institutional change. Moreover, it can allow theoretical and perhaps ultimately empirical comparison of different approaches.

\subsection{Government}

To derive the probability of the survival of democracy in a new, unconsolidated democracy in each period, we consider government's choice of $h_{t}$ and its effect on the public's beliefs.

\subsubsection{The government budget constraint}

The government is assumed to choose fiscal policy subject to an intertemporal budget constraint

$$
k_{t}+y=h_{t}+k_{t+1}
$$

where $k_{t}$ represents assets carried over from the previous period and $y$ is per-period flow income. To model most simply the effect of differences in $\sigma_{t}$ across periods, we consider two periods (say $t=1,2)$ in which $\sigma_{1} \neq \sigma_{2}$, where the budget must be balanced over the two periods. That is, if the government is not overthrown in a coup, we require it to bequeath to the $t=3$ government the same assets it received in period 1 , i.e., $k_{3}=k_{1}$, which is exogenously given. We assume that citizens in new democracies observe neither $h_{t}$ directly, nor can they infer it. This is consistent with the view (discussed further below) that in a new democracy citizens have quite imperfect information about 
fiscal policy, especially around election years.

\subsubsection{Affecting perceptions in a new democracy}

As indicated, the key characteristic of a new democracy in which democracy is not fully consolidated is that the government can devote resources to increasing the probability of a good outcome of event $Z$, that is, showing "democracy works". We model this simply by assuming that when the government spends $h_{t}$, the probability of a good economic outcome $S$ is $\mu\left(h_{t}\right)$, where $\mu^{\prime}(h)>0$ and $\mu^{\prime \prime}(h)<0$ (and the probability of the outcome $X$ is $1-\mu\left(h_{t}\right)$ ) For simplicity of exposition, we assume that the effect of $h$ on $\mu$ does not depend on $\nu$, the probability assigned to the government using $h$, which influences instead the posterior $P$ formed on observing a good outcome. ${ }^{11}$

For modeling simplicity, we have assumed that all citizens are influenced by the same expenditures in forming their inferences about democracy. In practice, different citizens will be affected by different programs. This may reflect numerous factors - geographic differences, rural versus urban allocations, and the socioeconomic, demographic, and ethnic distribution of the population. Since our basic argument may be illustrated using only a single type of expenditure, we have abstracted from this consideration in the model, but we return to the possible empirical significance of this point in section 3.4.2 below.

One may then use $\mu\left(h_{t}\right)$ to derive the probability that citizens assign to democracy being good conditional on the government's choice of $h_{t}$, namely:

$$
P_{t}\left(h_{t}\right)=\mu\left(h_{t}\right) P_{t}\left(\cdot \mid Z_{t}=S ; \nu\right)+\left(1-\mu\left(h_{t}\right)\right) P_{t}\left(\cdot \mid Z_{t}=X ; \nu\right)>0
$$

(This may be expanded using (5)) Since $P_{t}\left(\cdot \mid Z_{t}=S ; \nu\right)>P_{t}\left(\cdot \mid Z_{t}=X ; \nu\right)$ and $\mu^{\prime}(h)>0, P_{t}\left(h_{t}\right)$ in (11) is monotonically increasing in $h$. Using (7), (6), and (11), we may then define the probability of survival of democracy at any point as a function of $h_{t}$ by

$$
\sigma\left(h_{t}, t\right) \equiv 1-\xi\left[F\left(P_{t}\left(h_{t}\right)\right), t\right]
$$

Since $P_{t}\left(h_{t}\right)$ is monotonically increasing in $h$, the $\operatorname{CDF} F\left(P_{t}\right)$ is monotonically increasing in $P_{t}$, and $\xi\left(\phi_{t}, t\right)$ is monotonically decreasing in $\phi_{t}$, we have $\sigma_{h}(h, t)>0$. We will further assume that

\footnotetext{
${ }^{11}$ An alternative would be that higher $h$ increases $\nu$ by making it more likely that manipulation of outcomes would be observed. This would serve to reduce the effectiveness of increases in $h$ on affecting attitudes, giving an explicit basis for the assumption that $\mu^{\prime \prime}(h)<0$.
} 
$\sigma_{h h}(h, t)<0$. Concavity of $\sigma(h, t)$ further implies that

$$
\frac{d\left(\sigma_{h}(h, t) / \sigma(h, t)\right)}{d h}<0
$$

which will be crucial below. Characteristics of $\sigma(h, t)$ and $\sigma_{h}(h, t)$ as $h$ approaches either 0 or $\infty$ may be derived from the underlying functions $\mu(\cdot), F(\cdot)$, and $\xi(\cdot, t) .{ }^{12}$

\subsubsection{The government's choice problem}

Let the government's present discounted welfare in any period $t$ in which they start with $y_{t}$ be $\Omega\left(y_{t}\right)$ if in office and $\Psi$ if thrown out of office in a coup. Given the probability $\sigma\left(h_{t}, t\right)$ of surviving until period $t+1$ we may write

$$
\Omega\left(y+k_{t}\right)=\sigma\left(h_{t}, t\right) \Omega\left(y+k_{t+1}\right)+\left(1-\sigma\left(h_{t}, t\right)\right) \Psi
$$

which over periods 1 and 2 may be written (using the intertemporal budget constraint (10) as:

$$
\Omega\left(y+k_{1}\right)=\left(1-\sigma\left(k_{1}-k_{2}, 1\right)\right) \Psi+\sigma\left(k_{1}-k_{2}, 1\right)\left(\left(1-\sigma\left(k_{2}-k_{3}, 2\right)\right) \Psi+\sigma\left(k_{2}-k_{3}, 2\right) \Omega\left(y+k_{3}\right)\right)
$$

The government's choice problem is how to allocate resources to "protect" democracy over the two

periods, that is, what is the optimal value of $k_{2}$. Using the constraint that the budget is balanced over the two periods so that $k_{3}=k_{1}$, one obtains a first order condition

$$
\frac{d \Omega\left(y_{1}\right)}{d y_{2}}=\sigma_{h}[\cdot, 1] \Psi-\sigma_{h}[\cdot, 1]\left(\sigma[\cdot, 2] \Omega\left(y_{3}\right)+(1-\sigma[\cdot, 2]) \Psi\right)+\sigma[\cdot, 1] \sigma_{h}[\cdot, 2]\left(\Omega\left(y_{3}\right)-\Psi\right)=0
$$

which may be rearranged to yield

$$
\frac{\sigma_{h}\left(h_{1}, 1\right)}{\sigma\left(h_{1}, 1\right)}=\frac{\sigma_{h}\left(h_{2}, 2\right)}{\sigma\left(h_{2}, 2\right)}
$$

We now consider what are the implications of (16) for the pattern of $h_{t}$.

\subsection{The pattern of fiscal policy in a new democracy}

\footnotetext{
${ }^{12}$ Assume that as $\lim _{h \rightarrow \infty} \mu=1$ so that $P_{t}\left(h_{t}=\infty\right)=P_{t}\left(\cdot \mid Z_{t}=S ; \nu\right)$. Let $F\left[P_{t}\left(\cdot \mid Z_{t}=S ; \nu\right)\right]=\bar{\phi} \leq \hat{\phi}$, so that $\lim _{h \rightarrow \infty} \sigma\left(h_{t}, t\right)=\bar{\sigma} \leq 1$ and $\sigma\left(h_{t}, t\right)<\bar{\sigma}$ for $h_{t}<\infty$. When $h=0$ then the probability of observing $S$ is $\delta$ implying $P_{t}(0)=\delta P_{t}\left(\cdot \mid Z_{t}=S ; \nu\right)+(1-\delta) P_{t}\left(\cdot \mid Z_{t}=X ; \nu\right)$. Let $F\left[P_{t}(0)\right]=\underline{\phi} \geq 0$, so that $\lim _{h \rightarrow 0} \sigma\left(h_{t}, t\right)=\underline{\sigma}>0$. Finally, we assume that both $\sigma(h, t)$ and $\sigma_{h}(h, t)$ are continuous over the interval $(\underline{\sigma}, \bar{\sigma})$ so that $\lim _{h \rightarrow \infty} \sigma^{\prime}\left(h_{t}, t\right)=0$ and $\lim _{h \rightarrow 0} \sigma^{\prime}\left(h_{t}, t\right)=$ $\infty$.
} 
We ask how the attempt to affect public perceptions of democracy to prevent democratic collapse will affect the pattern of fiscal policy relative to an old democracy. When democracy is consolidated so that $P_{t}=1, \phi_{t}=\sigma_{t}=1$ regardless of the value of $h_{t}$, so that there is no need for $h_{t}>0$. In a longstanding but still fragile democracies (where $P_{t-1}<1$ ), we argued that because of voters' experience with fiscal policy and "election-year economics" attempts to manipulate economic outcomes will be perceived as such and hence unsuccessful. (In terms of equations (5), if manipulation takes place it will observed with probability $v=1$, so that $P_{t}=P_{t-1}$.) Hence, in the reference case of an old democracy, $h_{1}=h_{2}=0$.

\subsubsection{The timing of fiscal expenditures}

\section{Critical points of democratic vulnerability}

If the probability of democratic survival is the same across periods, that is, if $\sigma(\cdot, 1)=\sigma(\cdot, 2)$, then (16) implies $h_{1}=h_{2}$. The condition that $\lim _{h \rightarrow 0} \sigma^{\prime}\left(h_{t}, t\right)=\infty$ (see footnote 12) implies that $h_{1}=h_{2}>0$, but there will be no cycle in fiscal expenditures.

Suppose instead that there is a lower probability of survival in the first period, that is, $\sigma(h, 1)<$ $\sigma(h, 2)$ for any $h$. Moreover, assume that the elasticity of $\sigma(h, 1)$ with respect to $h$ is higher than the elasticity of $\sigma(h)$, that is

$$
\frac{h \sigma_{h}(h, 1)}{\sigma(h, 1)}>\frac{h \sigma_{h}(h, 2)}{\sigma(h, 2)}
$$

for all $h$, meaning roughly a greater sensitivity of survival to $h$ in period 1 than 2 . Hence, period 1 may be seen as a "critical" period.

One should note that the inequality (17) needn't arise from differences in the effect of $h_{t}$ on $\sigma\left(h_{t}, t\right)$, that is, from differences in the first derivative $\sigma_{h}\left(h_{t}, t\right)$. Even if $\sigma_{h}(h, 1)=\sigma_{h}(h, 2)$, a lower level of $\sigma(h, t)$, that is, $\sigma(h, 1)<\sigma(h, 2)$ for any $h$ will imply that (17) holds. In words, even if expenditures have the same effect on survival probabilities across periods, a lower survival probability in one period than the other for given expenditures will imply a higher level of $h$ in the more vulnerable period.

The concavity of $\sigma\left(h_{t}, t\right)$ in $h_{t}$ implies (see (12) above) that when (17) characterizes the difference between $\sigma(h, 1)$ and $\sigma(h, 2)$, the first-order condition (16) can only be satisfied for $h_{1}>h_{2}>0$. That is, higher vulnerability of democracy implies higher fiscal expenditures to affect public attitudes about democracy.

\section{Political Budget Cycles}

Based on data on the incidence of democratic collapse in new democracies in election versus non- 
election years (see section 4.1 below), we argue that periods around elections are periods of highest vulnerability of democracy. This seems logical since elections are often focal points for democratic discontent.

The association of election years with critical points of democratic vulnerability has a simple but important implication, namely the existence of political budget cycles in new democracies due solely to the fragility of democracy (and that wouldn't arise in old democracies). That is, in new democracies, fiscal policy will be characterized by higher expenditures in election than non-election years. The greater the differential in democratic vulnerability, the larger the political budget cycle.

Association of points of high vulnerability with election years raises the question of the effect of $h_{t}$ on re-election probabilities. Formally, the model could be seen as embodying the assumption that re-election is certain, that is, that the only reason an incumbent would lose office between $t=1$ and $t=2$ is a coup. Allowing there to be an exogenous probability $\rho<1$ of re-election at the end of $t=1$ would not change the basic conceptual argument. It would increase the benefit to the incumbent of $h_{1}$ relative to $h_{2}$ since even if no coup occurs at the end of $t=1$, the incumbent is in office in $t=2$ only with probability $\rho<1$.@13

A more basic question is whether the re-election probability $\rho$ would be affected by expenditures $h_{t}$. This would confound the association of $h_{t}$ with political budget cycles as derived above, since $h_{1}>h_{2}$ could reflect either higher vulnerability of democracy in election years or simply the attempt of the incumbent to win re-election (coupled with the belief that higher expenditures increase the chances of re-election). However, in Brender and Drazen (2005b) we find that expansionary fiscal policy does not help an incumbent in a new democracy get re-elected (and actually significantly lowers re-election probabilities in old democracies). Hence, were we to include re-election probabilities in the model explicitly, the most defensible assumption empirically is that the incumbent cannot influence his chances of winning a regular competitive election via fiscal policy, specifically by $h_{t}$. Conceptually, one may argue that $h_{t}$ affects $\sigma$ but not $\rho$ because to be effective, it must be directed at group wider than swing or core voters. That is, were the incumbent to target $h_{t}$ for electoral effectiveness, it might be seen by the public in general as confirming its skepticism about democracy and hence be counter productive.

\subsubsection{The size of fiscal expenditures}

\footnotetext{
${ }^{13}$ If $\rho<1$ this should also affectboth ND and OD, while $h$ is relevant only in ND. Hence, if we observe PBC only in ND, it is likely to reflect $h$ (especially given our findings on re-election). This is supported by Brender and Drazen's (2005b) finding that the probability of re-election in ND is larger (or at least not smaller) than in OD.
} 
A key question concerns the size of the difference between $h_{1}$ and $h_{2}$, that is, of the difference between expenditures to affect attitudes about democracy in periods of high versus low democratic variability. This will clearly depend on the characteristics of the function $\sigma\left(h_{t}, t\right)$ across time. The larger is the difference in the elasticity of $\sigma\left(h_{t}, t\right)$ between two periods, the larger will be the difference in $h_{t}$ between the two periods.

The size of $h_{t}$ depends on the characteristics of the function $\sigma\left(h_{t}, t\right)$ and its determinants. More specifically, the level and sensitivity of $\xi$, the probability of a successful overthrow of democracy as perceived by the elites, to $\phi$, support for democracy by the masses, is important. A low level of $\phi$ (that is, a high level of $\xi$ ) in the absence of government action, as well as a low sensitivity of $\xi$ to $\phi$ (so that a large increase in $\phi$ is needed to reduce $\xi$ significantly) will lead to higher level of expenditures $h$. Intuitively, if the public begins with a weak belief in democracy and this implies that anti-democratic elements think an anti-democratic coup has a large chance of success, government expenditure on consolidation will be high.

A second determinant is the sensitivity of good versus bad outcomes to fiscal policy is crucial. In terms of our specific model, how does the probability $\mu$ that a good outcome will be observed rise as expenditure $h$ increases? Intuitively, how costly is it for the regime to produce good outcomes, that is, outcomes that will induce citizens to support democracy? In practice this would depend, inter alia, on the magnitude of the problems facing the economy before the election year and on "luck" e.g., global developments. A negative external shock - such as a global slowdown or an increase in import prices - after democratization would make it more difficult - and costly - for the government to persuade the public that democracy can coexist with a functioning economy. Though we did not model it, a crucial characteristic of new democracies as shown in Tables 1 and $1 \mathrm{~A}$ is that voters do not see fiscal policy directed toward this end as manipulative. To the extent they learn about election-year manipulation, this sort of fiscal policy will be ineffective and hence less likely to be used.

A third determinant would be alternative uses of resources within a period when democracy is at risk. To better see the effect of this, return to the model of section 3.3.3 and suppose that first-period income may also be spent on $g_{1}$ that affect government (or public) utility directly. Suppose the government's objective, instead of (14) were to maximize

$$
\Omega\left(y+k_{1}\right)=u\left(g_{1}\right)+\left(1-\sigma\left(h_{1}, 1\right)\right) \Psi+\sigma\left(h_{1}, 1\right)\left(\left(1-\sigma\left(k_{2}-k_{3}, 2\right)\right) \Psi+\sigma\left(k_{2}-k_{3}, 2\right) \Omega\left(y_{3}\right)\right)
$$

subject to

$$
y+k_{1}=h_{1}+g_{1}+k_{2}
$$


One would obtain a first-order condition for $k_{2}$ which would be identical to (15) implying that $h_{1}$ and $h_{2}$ should be chosen to equalize $\frac{\sigma_{h}\left(h_{t}, t\right)}{\sigma\left(h_{t}, t\right)}$ across periods (implying that $h_{1}=h_{2}$ if $\sigma(\cdot, 1)=\sigma(\cdot, 2)$ ). In addition one would obtain a first-order condition for $g_{1}$, namely

$$
\sigma_{h}[\cdot, 1] \sigma[\cdot, 2]\left(\Omega\left(k_{3}\right)-\Psi\right)=u^{\prime}\left(g_{1}\right)
$$

determining the level of "regular utility-producing" expenditures $g_{1}$ relative to "attitude-affecting" expenditures $h_{1}$. The thing to notice from $(20)$ is that given $\sigma\left(h_{t}, t\right)$, the higher is $\Omega\left(k_{3}\right)-\Psi$ the lower will be $g_{1}$ and hence the higher will be $h_{1}$ (and $h_{2}$ ). This should be clear intuitively. $\Omega\left(k_{3}\right)-\Psi$ is the present discounted value of being in office in $t=2$ versus having been removed in a coup. The larger this is, the more resources - that is, the greater the fraction of the overall budget — will be devoted to expenditures aimed at remaining in office. Put another way, the greater is the cost of being deposed in a coup (the larger is $\Psi$ in absolute value), the larger will be expenditures meant to retain office. If the cost to a leader of being deposed in a coup is very large, as it may well be when democracy is quite new, expenditures $h_{t}$ to retain office may be quite large.

To conclude this section, the magnitude of expenditures to consolidate democracy depend of course on where they are directed. This is a further reason for looking at expenditures directed at the masses and not solely (or primarily) at the elites (which of course may be part of the process of democratic consolidation). To go a step further, we would argue that expenditures directed at elites would not be of sufficient magnitude to explain the magnitude of fiscal effect we discuss in the next section. ${ }^{14}$

\section{Some Supportive Evidence}

We now present a number of findings about new democracies that are consistent with our approach and that we think are supportive of our arguments on fiscal implications of democratic fragility in new democracies.

\subsection{Election years as points of vulnerability}

Our discussion of the problem of democratic consolidation suggests that in new democracies fiscal policy responds especially at certain "critical points" at which democracy may be especially

\footnotetext{
${ }^{14}$ We note however that when buying off elites is seen as critical to democracy surviving, the amount that needs to be given to elites to secure their support need not be proportional or correlated with their size. That is, a very powerful elite may be able to extract a disproportionate amount of resources from the government in order that they to secure their support for the regime.
} 
vulnerable. One such point is probably around elections. It is not simply that dissatisfaction can be expressed at ballot box, but also, almost "by definition" the democratic system is being tested at election time: a leader may cancel elections; turnover of parliament is time of mechanical fragility. In fact whether the first elections take place after the transition to democracy is generally seen as crucial to the legitimacy of a newly democratic system (See, for example, O'Donnell and Schmitter (1986) and Linz and Stepan(1978).)

In Table 2, we present the probability of democracy collapsing in both new and old democracies. We see that democracy is almost three times more likely to collapse in election years than non-election years in new democracies. It is also evident from the table that in old democracies the probability of a collapse of the democratic regime is very small, with similar values in election and non-election years.

[Put Table 2 Here]

\subsection{Election-year effects in new and old democracies}

If democratic fragility induces significant expenditures to help consolidate democracy at times of democratic vulnerability, then this should show up in the data. To the extent that these points of especially high vulnerability are election years, we should observe a political budget cycle with expenditures being higher in election than non-election years, though such an effect would not represent electoral manipulation in the standard sense. The absence of problems of democratic consolidation in old democracies (or the ineffectiveness of expenditures in affecting beliefs about democracy), combined with the absence of any apparent difference in the likelihood of democratic collapse between election and non-election years suggests that there should be no similar effect in old democracies.

In Brender and Drazen (2005a), we find that increases in the government expenditures and deficits (relative to GDP) in election years take place predominantly in new democracies, with no statistically significant cycle in older democracies as a group. ${ }^{15}$ In the period 1960-2001, the election year in the first elections (up to the first four) after the transition to democracy in 36 new democracies is characterized by an increase in public expenditure and the deficit of $0.8 \%$ of GDP. In contrast, in elections after the first four, as well as in established democracies, there is no statistically significant increase in the deficit relative to non-election years. We reproduce in Table 3 the first table of our earlier paper, showing this result. In the earlier paper, we also show that the significant difference between new and established democracies remains even after controlling for the level of democracy,

\footnotetext{
15 "New" democracies in our paper refered to up to the first four elections in a country after the transition to democracy, whereas elections after the first four are taken to refer to old or established democracies.
} 
the level of economic development, endogeneity of election dates, the electoral system and whether a country has a Presidential or a Parliamentary system.

\section{[Put Table 3 Here]}

Of course the finding of a significant election-year effect on government expenditures in new but not old democracies does not prove that these expenditures are motivated by the desire to prevent reversion to non-democracy at a critical point. However, Brender and Drazen (2005b) look at voter response to deficit spending in new democracies over the period 1960-2003 and find no evidence that high government expenditures or deficits affect the probability that the incumbent gets re-elected. In Table 4 we present some of the results from that paper. The point of the table is that while there is a significant increase in central government expenditures in election years, they do not serve to help an incumbent's re-election. This suggests that the election-year increase in government spending reported in Table 3 reflects something other than the attempt to improve re-election prospects. ${ }^{16}$

[Put Table 4 Here]

\subsection{The composition of election-year expenditures}

Unfortunately, in a large panel it is impossible to disaggregate the data to the level where one can identify expenditures as clearly aimed at affecting public attitudes about democracy. One can however ask whether the data are consistent with high election-year expenditures in new democracies going primarily to elites or being spread more broadly. Towards this end we looked at the cases of the large increases in election-year government spending in new democracies to get a sense of where expenditures are going. This is summarized in Table 5, where we look at the composition of the increase in expenditures in the election year in the 20 new democracies that had the largest such increase in the sample used by Brender and Drazen (2005a). Countries are ordered by the overall growth in expenditure in the election year (in percent of GDP) relative to the previous year, indicated by the number in parentheses after the election date. For each country the table compares the fraction of the increase in public expenditures that was due to each of 4 spending categories (with the share of each category in total spending in the year before the election in the left-hand column in each category). A larger figure in the right-hand column than in the left-hand column in each category indicates a more than proportional share of that item in the election-year spending expansion. Overall, it seems that the increase in public spending in election years tended to be proportional to the composition of spending before the election year with the share of social spending

\footnotetext{
${ }^{16}$ We find unconvincing the argument that these increases reflect incumbents' attempts to influence voters, but they are repeatedly unsucessful.
} 
(welfare transfer payments, education and health) unchanged on average. ${ }^{17}$ The detailed composition of the increase in spending suggests that it was mostly transfer payments, agricultural subsidies to restore food supplies, or payment of arrears to utility suppliers that accounted for the increased spending in the election years. While not offering an unequivocal proof, these expenditures can more intuitively be classified as spending on the masses than on elites.

[Put Table 5 Here]

\subsection{Fiscal manipulation}

For high expenditures to be consistent with the government trying to show that "democracy works", we argued that they cannot be perceived as such. To buttress this claim, we argued that fiscal manipulation is less observable in new democracies. A somewhat rough indication of this can be drawn from Table 6. In this table we compare the data on public expenditure as reported in the IFS in the year subsequent to the one for which the data are reported with the latest available data for the same year. ${ }^{18}$ We find that in new democracies the level of expenditure reported immediately after the election year were 1.4 percent lower than finalized data; in non-election years, it was unchanged. In contrast, in established democracies initial reports for election years were 0.1 percent lower than the final data, compared to their being 0.2 percent higher in non-election years. While a comprehensive analysis of the differences in the quality of reporting in various groups of countries is beyond the scope of this paper, these figures are suggestive that new democracies provide a lower quality of data to their citizens in election years.

\section{[Put Table 6 Here]}

\section{Concluding Comments}

There are many countries where democracy is new and hence often not fully consolidated. The purpose of this paper was to explore how the danger of a collapse of democracy may affect fiscal policy in comparison to countries where democracy is older and often more established. The question of the implications of democratic fragility for economic policy has received considerable attention from political scientists, though formal modeling is far more recent and less common. A common theme of much of the literature is that elites play a crucial role both in the transition to democracy and in the possibility of reversion of a democracy to autocracy. While this is uncontroversial, this view has

\footnotetext{
${ }^{17}$ The noticeable outlier Ethiopia reflects the combined effects of the war with Eritrea and famine which required higher military spending and agricultural subsidies.

${ }^{18}$ For example, we compare the data for Spain in 1982, as reported in the 1983 IFS, with the data for Spain in the same year as reported in the 2005 IFS.
} 
lead many researchers to focus primarily on policies aimed at anti-democratic elites in consolidation of democracy with far less attention paid to policies aimed at the mass of citizenry.

In this paper we concentrate on the citizenry and consider policy meant to affect their attitudes towards democracy, more specifically, at policy meant to convince a possibly skeptical citizenry that "democracy works". Our focus therefore is on the inference problem that citizens solve in looking at economic outcomes and forming their beliefs about the efficacy of democracy. Our interest is not in analyzing very specific policies, but in the general implications of the need to address the concerns of citizens for patterns of fiscal policy in new democracies. We argued that the implications of the model are broadly consistent with the empirical patterns generally observed, including the existence of political budget cycles in new democracies that are not observed in the aggregate budget level in a panel of old democracies.

As discussed in section 3.2.1, our model can represent different important approaches to studying consolidation of democracy that are complementary to one another. It therefore suggests that these approaches can be compared in a common framework which can be used to study the relative importance of the various factors affecting the consolidation process in different countries or episodes. We hope this paper encourages further research in that direction. 


\section{References}

Acemoglu, D. and J. Robinson (2005), Economic Origins of Dictatorship and Democracy, Cambridge, UK: Cambridge University Press.

Bermeo, N. (2003), Ordinary People in Extraordinary Times: The Citizenry and the Breakdown of Democracy, Princeton, NJ: Princeton University Press.

Bernhard, Reenock, and Nordstrom, (2003), "Economic Performance and Survival in New Democracies: Is there a Honeymoon Effect?," Comparative Political Studies 36, 404-431.

Brender, A. (2003), "The Effect of Fiscal Performance on Local Government Election Results in Israel: 1989-1998," Journal of Public Economics 87, 2187-2205.

Brender, A. and A. Drazen (2005a), "Political Budget Cycles in New Versus Established Democracies", Journal of Monetary Economics 52, October 2005.

(2005b), "How Do Budget Deficits and Economic Growth Affect Reelection Prospects?," NBER Working Paper 11862.

Diamond, L. (1994), "Toward Democratic Consolidation," Journal of Democracy 5.

Gillespie, C. (1991), "The Role of Civil-Military Pacts in Elite Settlements and Elite Convergence: Democratic Consolidation in Uruguay," in Gunther and Higley, eds. Elites and Democratic Consolidation, Cambridge: Cambridge University Press.

Huntington, S. (1993), The Third Wave: Democratization in the Late Twentieth Century, Norman, OK: University of Oklahoma Press.

Inglehart, R., et al. (2004), World Values Surveys and European Values Surveys, 1999-2001, Ann Arbor, MI: Inter-university Consortium for Political and Social Research.

Linz, J.J., and A. Stepan (1978), The Breakdown of Democratic Regimes, Baltimore, MD: Johns Hopkins University Press.

(1996), Problems of Democratic Transition and Consolidation: Southern Europe, South America, and Post-Communist Europe, Baltimore, MD: Johns Hopkins University Press.

Mainwaring, S. (1992), "Transitions to Democracy and Democratic Consolidation: Theoretical and Comparative Issues," working paper.

O'Donnell, G. and P. Schmitter (1986), Transitions from Authoritarian Rule: Tentative Conclusions about Uncertain Democracies, Baltimore: Johns Hopkins University Press.

Przeworski, A., M.E. Alvarez, J. Cheibub, and F. Limongi (2000), Democracy and Development : Political Institutions and Well-Being in the World, 1950-1990, Cambridge, UK: Cambridge University Press.

Remmer, K. (1996), "The Sustainability of Political Democracy: Lessons from South America," Comparative Political Studies 29, 611-634.

Rogoff, K. (1990), "Equilibrium Political Budget Cycles," American Economic Review 80, 21-36.

Rogoff, K. and A. Sibert (1988), "Elections and Macroeconomic Policy Cycles," Review of Economic Studies 55, 1-16.

Rustow, D.C. (1970), "Transitions to Democracy: Toward a Dynamic Model," Comparative Politics 2, 337-363.

Schedler, A. (1998) "What is Democratic Consolidation?" Journal of Democracy, 9, 91-107.

Tavares, J. and R. Wacziarg (2001), "How Democracy Affects Growth," European Economic Review 45, 1341-1378. 


\section{Figure 1: The Difference in Attitudes Between Citizens of New and Old Democracies by Age $^{1}$}

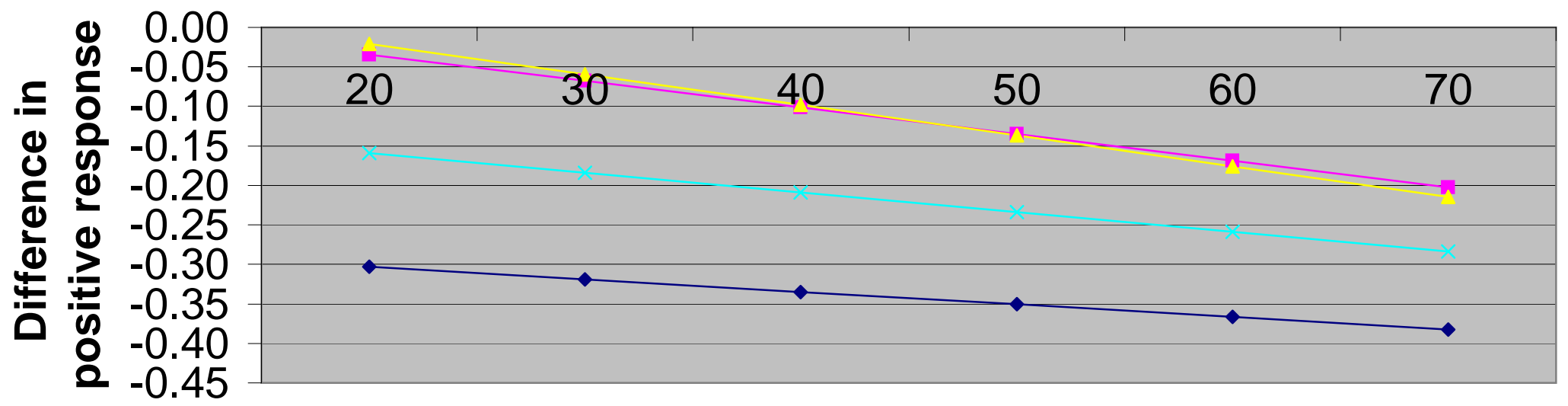

Age

$\rightarrow$ Freedom of speech is important $\rightarrow$ - Democracy is good Evaluation of democracy's progress * Superiority of democracy

${ }^{1}$ Values in the Figure are differences between citizens of new and old democracies in the response to positive statements about democracy. 
Table 1: Differences in Attitudes and Preferences Between Citizens in New and Established Democracies ${ }^{1}$

\begin{tabular}{|c|c|c|c|c|c|c|c|c|}
\hline \multirow{2}{*}{ Significance of economic performance: } & $\begin{array}{c}\text { New } \\
\text { Democracy }\end{array}$ & $\begin{array}{l}\text { GDP per } \\
\text { capita } \\
(1,000 \$) \\
\end{array}$ & \begin{tabular}{|c}
$\begin{array}{c}\text { Share of } \\
\text { population } \\
\text { in ages } \\
15-64 \\
\end{array}$ \\
\end{tabular} & $\begin{array}{c}\text { Share of } \\
\text { population } \\
\text { over age } 64 \\
\end{array}$ & Constant & $\mathbf{N}$ & \begin{tabular}{|c|} 
of which: new \\
democracies
\end{tabular} \mid & Adj. $R^{2}$ \\
\hline & & & & & & & & \\
\hline Growth is important ${ }^{2}$ & $\begin{array}{l}0.049^{* *} \\
{[0.028]}\end{array}$ & $\begin{array}{l}-0.005^{* * *} \\
{[0.005]}\end{array}$ & $\begin{array}{l}-0.005^{*} \\
{[0.073]}\end{array}$ & $\begin{array}{l}0.007^{* *} \\
{[0.010]}\end{array}$ & $\begin{array}{l}1.088^{* * *} \\
{[0.000]}\end{array}$ & 91 & 47 & 0.32 \\
\hline Stable economic progress is important ${ }^{3}$ & $\begin{array}{l}0.110^{* * *} \\
{[0.000]}\end{array}$ & $\begin{array}{l}-0.003 \\
{[0.226]}\end{array}$ & $\begin{array}{l}0.005 \\
{[0.152]}\end{array}$ & $\begin{array}{l}0.001 \\
{[0.839]}\end{array}$ & $\begin{array}{l}0.35 \\
{[0.108]}\end{array}$ & 92 & 48 & 0.302 \\
\hline Attitudes toward democracy and politics: & & & & & & & & \\
\hline Democracy is good ${ }^{4}$ & $\mid \begin{array}{l}-0.171^{* * *} \\
{[0.004]}\end{array}$ & $\begin{array}{l}0.006 \\
{[0.126]}\end{array}$ & $\begin{array}{l}-0.028^{* * *} \\
{[0.001]}\end{array}$ & $\begin{array}{l}0.004 \\
{[0.561]}\end{array}$ & $\begin{array}{l}5.104^{* * *} \\
{[0.000]}\end{array}$ & 86 & 47 & 0.342 \\
\hline Maintaining order is important ${ }^{5}$ & $\begin{array}{l}0.077^{* *} \\
{[0.012]}\end{array}$ & $\begin{array}{l}-0.004^{*} \\
{[0.062]}\end{array}$ & $\begin{array}{l}-0.005 \\
{[0.250]}\end{array}$ & $\begin{array}{l}0.006 \\
{[0.120]}\end{array}$ & $\begin{array}{l}0.703^{* * *} \\
{[0.006]}\end{array}$ & 137 & 62 & 0.144 \\
\hline Freedom of speech is important ${ }^{6}$ & $\begin{array}{l}-0.052^{* * *} \\
{[0.001]}\end{array}$ & $\begin{array}{l}0.004^{* * *} \\
{[0.001]}\end{array}$ & $\begin{array}{l}-0.001 \\
{[0.718]}\end{array}$ & $\begin{array}{l}0 \\
{[0.813]}\end{array}$ & $\begin{array}{l}0.161 \\
{[0.223]}\end{array}$ & 137 & 62 & 0.322 \\
\hline Evaluation of democracy's progress ${ }^{7}$ & $\begin{array}{l}-0.203^{* *} \\
{[0.048]}\end{array}$ & $\begin{array}{l}0.018^{* * *} \\
{[0.002]}\end{array}$ & $\begin{array}{l}-0.041^{* * *} \\
{[0.003]}\end{array}$ & $\begin{array}{l}-0.013 \\
{[0.299]}\end{array}$ & $\begin{array}{l}5.087^{* * *} \\
{[0.000]}\end{array}$ & 50 & 26 & 0.519 \\
\hline $\begin{array}{l}\text { Superiority of democracy }{ }^{8} \\
\text { Honesty and Government }\end{array}$ & $\mid \begin{array}{l}-0.208^{* * *} \\
{[0.002]}\end{array}$ & $\begin{array}{l}0.006 \\
{[0.179]}\end{array}$ & $\begin{array}{l}-0.016^{*} \\
{[0.079]}\end{array}$ & $\begin{array}{l}0.005 \\
{[0.517]}\end{array}$ & $\begin{array}{l}4.257^{* * *} \\
{[0.000]}\end{array}$ & 85 & 47 & 0.319 \\
\hline Cheating to get government benefits ${ }^{9}$ & $\begin{array}{l}0.584^{* * *} \\
{[0.000]}\end{array}$ & $\begin{array}{l}0.012 \\
{[0.272]}\end{array}$ & $\begin{array}{l}0.019 \\
{[0.437]}\end{array}$ & $\begin{array}{l}-0.042^{*} \\
{[0.057]}\end{array}$ & $\begin{array}{l}1.129 \\
{[0.431]}\end{array}$ & 134 & 59 & 0.152 \\
\hline Avoiding fares on public transport ${ }^{10}$ & $\begin{array}{l}0.650^{* * *} \\
{[0.000]}\end{array}$ & $\begin{array}{l}-0.002 \\
{[0.851]}\end{array}$ & $\begin{array}{l}0.012 \\
{[0.603]}\end{array}$ & $\begin{array}{l}0.015 \\
{[0.456]}\end{array}$ & $\begin{array}{l}1.3 \\
{[0.321]}\end{array}$ & 121 & 53 & 0.171 \\
\hline Following politics on the media ${ }^{11}$ & $\begin{array}{l}0.215 \\
{[0.160]}\end{array}$ & $\begin{array}{l}-0.002 \\
{[0.787]}\end{array}$ & $\begin{array}{l}0.017 \\
{[0.424]}\end{array}$ & $\begin{array}{l}0.038^{* *} \\
{[0.047]}\end{array}$ & $\begin{array}{l}1.158 \\
{[0.367]}\end{array}$ & 48 & 23 & 0.205 \\
\hline
\end{tabular}

Based on the mean responses of citizens' in various countries to the World Values Survey (Inglehart (2004). The figures in the first row for each question are regression coefficients and the figures in the second row are $P$ values.

\footnotetext{
$\frac{1}{2}$ The share of respondents stating that a "high level of economic growth" is one of the two most important goals their country should aim for in the
} 
next 10 years. The other options were "making sure that the country has strong defense forces", "seeing that people have more say about how things are done at their jobs and in their communities" and "trying to make our cities and countryside more beautiful".

${ }^{3}$ The share of respondents stating that a "stable economy" is one of the two most important goals their country should aim for in the next 10 years. The other options were "progress toward a less impersonal and more humane society", "progress toward a society in which ideas count more than money" and "the fight against crime".

${ }^{4}$ The means of respondents' opinions of the democratic system as a way of governing their country. The possible answers (on a scale of 4 ) ranged from "very bad" to "very good".

${ }^{5}$ The share of respondents stating that "maintaining order in the nation" is the most important goal their country should aim for in the next 10 years. The other options were "giving people more say in important government decisions", "fighting rising prices" and "protecting freedom of speech".

${ }^{6}$ The share of respondents stating that "protecting freedom of speech" is the most important goal their country should aim for in the next 10 years. The other options were "giving people more say in important government decisions", "fighting rising prices" and "maintaining order in the nation".

${ }^{7}$ The means of respondents' satisfaction with the progress of democracy in their country. The possible answers (on a scale of 4 ) ranged from "not at all satisfied" to "very satisfied".

'The means of respondents' agreement with the statement "Democracy may have problems but it's better than any other form of government". The possible answers (on a scale of 4) ranged from "strongly disagree" to "agree strongly".

${ }^{9}$ The means of respondents' opinions on how justifiable it is to claim government benefits to which one is not entitled. The possible answers (on a scale of 10) ranged from "never justifiable" to "always justifiable".

${ }_{10}$ The means of respondents' opinions on how justifiable it is to avoid a fare on public transport. The possible answers (on a scale of 10) ranged from "never justifiable" to "always justifiable".

${ }^{11}$ The means of respondents' answers to the question "How often do you follow politics in the news on television or on the radio or in the daily papers". The possible answers (on a scale of 5) ranged from "never" to "every day".

${ }^{*}$ - Significant at the 10 percent level; ${ }^{* *}$ - Significant at the 5 percent level; ${ }^{* * *}$ - Significant at the 1 percent level. 
Table 1A: Differences in Attitudes and Preferences Between Citizens in New and Established Democracies ${ }^{1}$

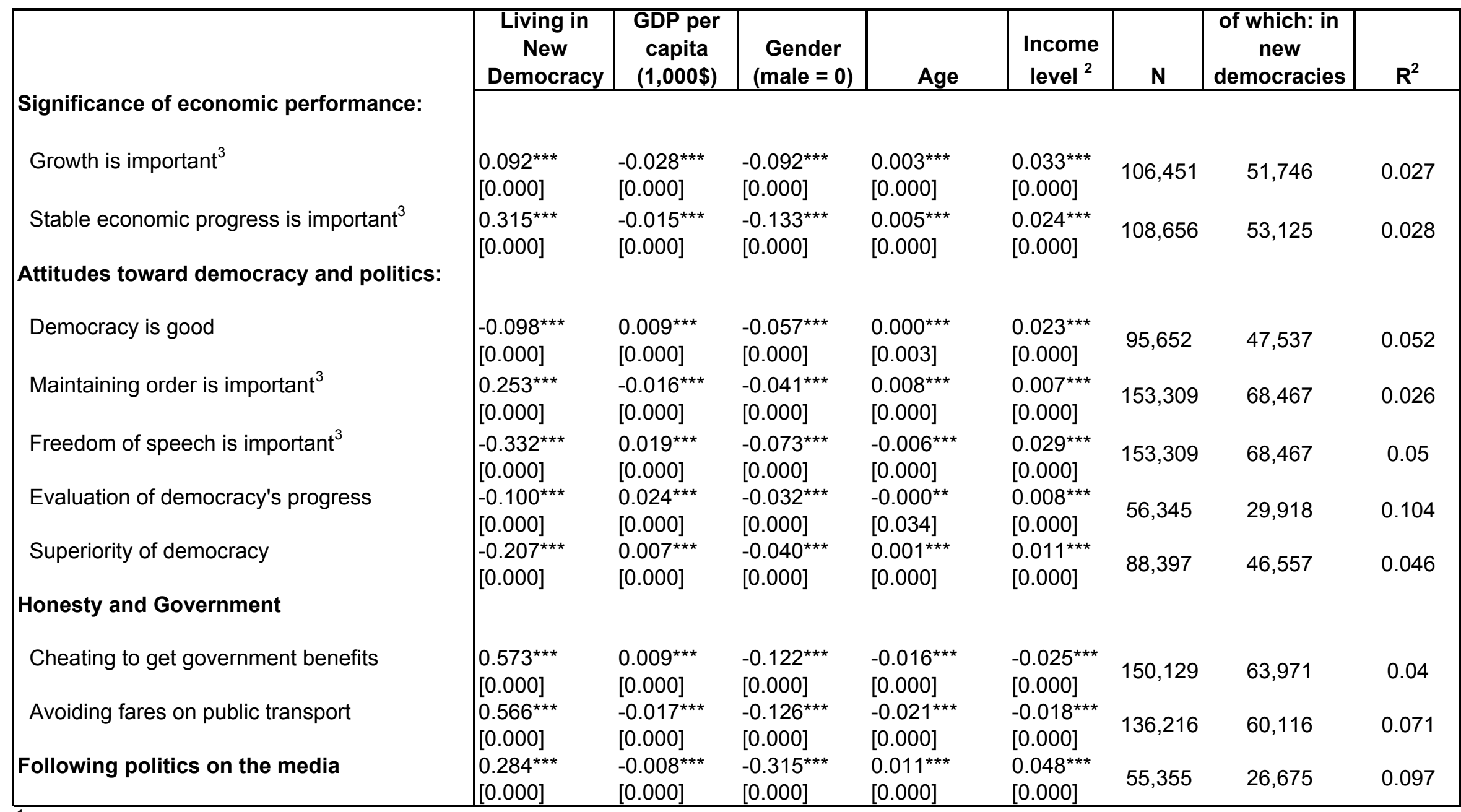

Based on the responses of citizens' in various countries to the World Values Survey (Inglehart (2004). The detailed questions appear in Table 2.

Controls also included the age composition of the country, marital status, employment status and religion (in a 7 groups distribution). The figures in the first row for each question are regression coefficients and the figures in the second row are $\mathrm{P}$ values.

${ }^{2}$ The income level of the individual in his country on a scale of $1-10$, where 1 is the lowest level.

${ }^{3}$ Probit equations.

* - Significant at the 10 percent level; ${ }^{* *}$ - Significant at the 5 percent level; *** - Significant at the 1 percent level. 
Table 2: The Fall of Democracies in Election and Non-Election Years

\begin{tabular}{|c|c|c|c|c|c|c|c|}
\hline & \multicolumn{3}{|c|}{ New Democracies ${ }^{1}$} & \multicolumn{3}{|c|}{ Old Democracies $^{1}$} \\
\hline & & \multicolumn{6}{|c|}{ (Percent of all the years in the column) } \\
\hline & & & $\begin{array}{l}\text { Other } \\
\text { years }\end{array}$ & \begin{tabular}{|l} 
Total No. of \\
Observations
\end{tabular} & Election Years & $\begin{array}{l}\text { Other } \\
\text { years }\end{array}$ & \begin{tabular}{|l} 
Total No. of \\
Observations
\end{tabular} \\
\hline \multirow[t]{2}{*}{$\begin{array}{l}\text { Fall of } \\
\text { Democracy }^{2}\end{array}$} & yes & 8.5 & 3.0 & 37 & 0.4 & 0.7 & 10 \\
\hline & no & 91.5 & 97.0 & 974 & 99.6 & 99.3 & 1,419 \\
\hline \multirow{2}{*}{$\begin{array}{l}\text { Sharp decline in } \\
\text { the level of } \\
\text { democracy }^{3}\end{array}$} & yes & 10.8 & 3.5 & 45 & 0.4 & 0.7 & 9 \\
\hline & no & 89.2 & 96.5 & 966 & 99.6 & 99.3 & 1,420 \\
\hline $\begin{array}{l}\text { A decine or } z \text { or } \\
\text { more points in } \\
\text { the level of } \\
\text { democracy }\end{array}$ & yes & 12.3 & 96.1 & 961 & 99.6 & 98.8 & 1,413 \\
\hline Total Years & & 130 & 881 & 1,011 & 228 & 1,201 & 1,429 \\
\hline
\end{tabular}

${ }^{1}$ Countries are defined as new democracies until the $4^{\text {th }}$ democratic election campaign.

${ }^{2} \mathrm{~A}$ downfall of a democracy is defined as a shift from a positive score in the democracy/autocracy scale in the POLITY IV dataset of the University of Maryland.

${ }^{3}$ Defined as a decline of 5 or more points in the democracy/autocracy scale, starting with a positive level.

${ }^{4}$ Starting from a positive level. 
Table 3: The Political Budget Cycle Across Countries, Fixed Effects Estimates.

\begin{tabular}{|c|c|c|c|c|c|c|c|c|c|c|c|c|}
\hline \multirow{4}{*}{$\begin{array}{l}\text { Estimation period } \\
\text { Dependent variable }^{1}\end{array}$} & \multicolumn{3}{|c|}{ All Democracies } & \multicolumn{3}{|c|}{ All "New Democracies" } & \multicolumn{3}{|c|}{$\begin{array}{l}\text { "New Democracies" } \\
\text { Excluding "Transition } \\
\text { Economies" }^{3}\end{array}$} & \multicolumn{3}{|c|}{ "Old Democracies" } \\
\hline & \multirow{2}{*}{\multicolumn{3}{|c|}{$\begin{array}{c}\frac{(1)}{1960-2001} \\
\end{array}$}} & \multirow{2}{*}{\multicolumn{3}{|c|}{$\begin{array}{c}(2) \\
1960-2001\end{array}$}} & \multirow{2}{*}{\multicolumn{3}{|c|}{$\begin{array}{c}(3) \\
1960-2001\end{array}$}} & \multirow{2}{*}{\multicolumn{3}{|c|}{$\frac{(4)}{1960-2001}$}} \\
\hline & & $960-200$ & & & & & & & & & & \\
\hline & balance & texp & $\operatorname{trg}$ & balance & texp & $\operatorname{trg}$ & balance & texp & $\operatorname{trg}$ & balance & texp & $\operatorname{trg}$ \\
\hline Elect $^{2}$ & $\begin{array}{c}-0.352^{\star * \star} \\
(0.123)\end{array}$ & $\begin{array}{c}0.085 \\
(0.193)\end{array}$ & $\begin{array}{l}-0.251 \\
(0.171)\end{array}$ & $\begin{array}{c}-0.868^{\star * *} \\
(0.273)\end{array}$ & $\begin{array}{l}0.747^{* *} \\
(0.292)\end{array}$ & $\begin{array}{l}-0.153 \\
(0.236)\end{array}$ & $\begin{array}{l}-0.684^{\star \star} \\
(0.290)\end{array}$ & $\begin{array}{l}0.434^{*} \\
(0.260)\end{array}$ & $\begin{array}{l}-0.237 \\
(0.247)\end{array}$ & $\begin{array}{l}-0.109 \\
(0.135)\end{array}$ & $\begin{array}{l}-0.131 \\
(0.146)\end{array}$ & $\begin{array}{l}-0.223^{*} \\
(0.118)\end{array}$ \\
\hline Adjusted $\mathrm{R}^{2}$ & 0.683 & 0.905 & 0.915 & 0.461 & 0.937 & 0.954 & 0.504 & 0.928 & 0.920 & 0.764 & 0.959 & 0.969 \\
\hline F- Statistic & 47.96 & 211.63 & 239.87 & 9.42 & 150.57 & 203.18 & 11.62 & 140.19 & 120.61 & 94.937 & 693.30 & 928.81 \\
\hline DW Statistic & 1.955 & 1.562 & 1.455 & 1.821 & 2.051 & 2.114 & 1.682 & 1.925 & 2.134 & 1.900 & 1.987 & 1.872 \\
\hline No. of countries & 68 & 68 & 68 & 36 & 36 & 36 & 26 & 26 & 26 & 32 & 32 & 32 \\
\hline No. of obs. & 1616 & 1631 & 1640 & 415 & 423 & 415 & 336 & 344 & 336 & 1105 & 1112 & 1128 \\
\hline Avg. time series length & 23.8 & 24.0 & 24.1 & 11.5 & 11.8 & 11.5 & 13.0 & 13.3 & 13.0 & 34.5 & 34.8 & 35.3 \\
\hline
\end{tabular}

This table is Table 1 of Brender and Drazen (2005a). In that paper we also presented GMM estimates of these relations, with basically identical results. The covariates include one lag of the dependent variable, the log of per-capita GDP, the ratio of international trade to GDP, the fraction of the population over age 65 , the fraction of the population between ages 15 and 64, and the log difference between real GDP and its (country specific) trend, estimated using a Hodrick-Prescott filter.

${ }^{1}$ Variable definitions (all in percent of GDP): balance-central government surplus; texp-total expenditure by the central government; trg-total revenue and grants of the central government. Standard errors are in the parentheses.

${ }^{2}$ Elect - a dummy variable with the value 1 in the election year and 0 otherwise.

${ }^{3}$ The "new democracies" among the transition economies are listed in Table A-I of Brender and Drazen (2005a).

* - Significant at the 10 percent level; ${ }^{* *}$ - Significant at the 5 percent level; ${ }^{\star \star *}$ - Significant at the 1 percent level. 
Table 4: The Effects of Budget Surpluses and Growth on the Probability of Reelection in New and Old Democracies ${ }^{1}$

\begin{tabular}{|c|c|}
\hline Dependent variable: Probability of Reelection ${ }^{1}$ & \\
\hline SURPLUS_term * old ${ }^{2}$ & $\begin{array}{l}10.709 * \star \\
{[0.018]}\end{array}$ \\
\hline SURPLUS_term * new_democracy ${ }^{2}$ & $\begin{array}{l}0.559 \\
{[0.956]}\end{array}$ \\
\hline SURPLUS_ey * old ${ }^{2}$ & $\begin{array}{l}10.373^{*} \\
{[0.078]}\end{array}$ \\
\hline SURPLUS_ey * new_democracy ${ }^{2}$ & $\begin{array}{l}6.702 \\
{[0.361]}\end{array}$ \\
\hline GDPPC_gr * old $^{2}$ & $\begin{array}{l}6.330 \\
{[0.170]}\end{array}$ \\
\hline GDPPC_gr * new_democracy ${ }^{2}$ & $\begin{array}{l}22.064^{\star \star \star} \\
{[0.002]}\end{array}$ \\
\hline Developed Countries & $\begin{array}{l}0.468^{\star *} \\
{[0.020]}\end{array}$ \\
\hline Majoritarian Electoral System & $\begin{array}{l}0.489 * * \\
{[0.011]}\end{array}$ \\
\hline Constant & $\begin{array}{l}-0.674^{\star \star *} \\
{[0.002]}\end{array}$ \\
\hline Pseudo $\mathbf{R}^{2}$ & 0.075 \\
\hline Akaike's criteria & 344.97 \\
\hline Schwartz's criteria & 376.84 \\
\hline Observations & 255 \\
\hline
\end{tabular}

${ }^{1}$ This table is taken from Brender and Drazen (2005b). The figures in the table are probit coefficients and the figures in the parentheses are Pvalues. An asterisk $\left(^{*}\right)$ indicates multiplication by the binary variable that follows. new_democracy - A binary variable with a value of 1 for new democracies, old - A binary variable with a value of 1 for old democracies. ${ }^{2}$ SURPLUS_term - The change in the ratio of the government deficit to GDP in the two years preceding the election year, relative to the two previous years. SURPLUS_ey -The change in the government deficit ratio to GDP In the election year, compared to the previous year. GDPPC gr The average growth rate of real per-capita GDP during the leader's current term.

* - Significant at the 10 percent level; ** - Significant at the 5 percent level; *** - Significant at the 1 percent level. 
Table 5: The Composition of Expenditure Increases in Election Years

\begin{tabular}{|c|c|c|c|c|c|c|c|c|}
\hline \begin{tabular}{|l} 
Country (Expenditure \\
Growth in percent)
\end{tabular} & \begin{tabular}{|c} 
Social Exp \\
Expenditure in the year \\
before the elections (out \\
of total expenditure)
\end{tabular} & $\begin{array}{l}\text { Fraction of total } \\
\text { election-year } \\
\text { expenditure growth } \\
\text { accounted for by this } \\
\text { category } \\
\end{array}$ & $\begin{array}{c}\text { Expenditure in the year } \\
\text { before the elections (out } \\
\text { of total expenditure) }\end{array}$ & $\begin{array}{l}\text { Infrastructure } \\
\text { Fraction of total election- } \\
\text { year expenditure growth } \\
\text { accounted for by this } \\
\text { category }\end{array}$ & \begin{tabular}{|c} 
Agricu \\
$\begin{array}{l}\text { Expenditure in the year } \\
\text { before the elections (out } \\
\text { of total expenditure) }\end{array}$ \\
\end{tabular} & $\begin{array}{l}\text { ulture } \\
\text { Fraction of total } \\
\text { election-year } \\
\text { expenditure growth } \\
\text { accounted for by this } \\
\text { category }\end{array}$ & $\begin{array}{c}\text { Expenditure in the year } \\
\text { before the elections (out } \\
\text { of total expenditure) }\end{array}$ & $\begin{array}{l}\text { Fraction of total } \\
\text { election-year } \\
\text { expenditure growth } \\
\text { accounted for by this } \\
\text { category } \\
\end{array}$ \\
\hline Brazil_1989 (8.85) & 31.3 & 37.4 & 4.1 & -3.1 & 2.0 & 0.7 & 62.6 & 65.0 \\
\hline Turkey_1977 (7.91) & 28.3 & 24.0 & 29.8 & 26.9 & 3.2 & 2.1 & 38.6 & 47.0 \\
\hline Greece_1981 (3.83) & 51.6 & 66.3 & 7.2 & 0.0 & 5.3 & 14.5 & 36.0 & 19.2 \\
\hline Bolivia_1993 (3.76) & 37.5 & 57.0 & 12.4 & 26.0 & 1.8 & 1.4 & 48.3 & 15.6 \\
\hline Turkey_1991 (3.62) & 26.3 & 12.1 & 12.9 & 17.1 & 2.0 & 2.0 & 58.7 & 68.8 \\
\hline Hungary_2002 (3.56) & 42.7 & 30.1 & 2.2 & 83.9 & 4.0 & 10.3 & 51.1 & -24.2 \\
\hline Cyprus_1973 (3.47) & 35.8 & 20.8 & 11.1 & -5.2 & 14.8 & 62.1 & 38.3 & 22.2 \\
\hline Estonia_1995 (3.15) & 59.6 & -1.8 & 7.1 & 2.4 & 1.6 & 58.7 & 31.7 & 40.7 \\
\hline Spain_1982 (3.08) & 68.8 & 104.7 & 3.4 & 9.6 & 3.3 & 1.5 & 24.4 & -15.8 \\
\hline Ethiopia_1999 (2.67) & 26.3 & -22.6 & 12.0 & 10.5 & 8.1 & 42.9 & 53.5 & 69.2 \\
\hline Jamaica_1976 (2.59) & 39.4 & 44.8 & 10.0 & 4.2 & 6.3 & 24.3 & 44.4 & 26.7 \\
\hline Cyprus_1983 (2.46) & 41.8 & 14.4 & 4.7 & 24.1 & 14.4 & 26.6 & 39.1 & 35.0 \\
\hline Mongolia_1997 (2.44) & 31.9 & 39.1 & 8.8 & -4.4 & 2.2 & 3.0 & 57.2 & 62.2 \\
\hline Brazil_1998 (2.29) & 57.5 & 89.7 & 1.7 & 0.2 & 2.6 & 1.6 & 38.2 & 8.4 \\
\hline Uruguay_1994 (1.96) & 73.6 & 65.6 & 4.3 & 3.9 & 1.1 & 1.2 & 21.0 & 29.3 \\
\hline Fij_1977 (1.90) & 37.9 & 73.2 & 17.2 & 0.3 & 8.0 & 3.0 & 36.9 & 23.5 \\
\hline Argentina_1999 (1.59) & 60.8 & 38.8 & 4.6 & -4.1 & 0.9 & -1.2 & 33.6 & 66.5 \\
\hline Nepal_1995 (1.53) & 24.1 & 8.5 & 13.3 & 16.4 & 11.0 & -4.5 & 51.6 & 79.6 \\
\hline Spain_1979 (1.50) & 67.9 & 83.9 & 3.2 & 10.9 & 3.6 & -5.9 & 25.3 & 11.1 \\
\hline Fiji_1982 (1.42) & 31.6 & 52.3 & 26.3 & 1.2 & 6.5 & 0.2 & 35.5 & 46.2 \\
\hline Average & 44.4 & 41.4 & 8.9 & 11.6 & 5.1 & 12.9 & 41.6 & 34.2 \\
\hline
\end{tabular}

Social Expenditure: Education, Health, Social Security \& Welfare, Housing \& Community Amenities

Services and Infrastructure: Economic Services: Fuel \& Energy, Transportation \& Communicatior

Agriculture: Economic Services: Agriculture, Forestry, Fishing, Huntinc 
Table 6: The Accuracy of Reported Expenditures in New and Old Democracies ${ }^{1}$

(In percent of the initially reported expenditures)

\begin{tabular}{|l|lccc|}
\multicolumn{2}{c}{} & \multicolumn{3}{c|}{ Non-election } \\
\hline All Countries & All Years & Election Years & Years \\
& deviation & -0.03 & -0.42 & 0.11 \\
Number of available years & 561 & 150 & 411 \\
& & -0.38 & -1.43 & -0.04 \\
Old Democracies & deviation & 161 & 39 & 122 \\
& Number of available years & & & \\
& deviation & 0.11 & -0.06 & 0.17 \\
Developed countries & Number of available years & 400 & 111 & 289 \\
& deviation & 0.22 & 0.15 & 0.25 \\
& Number of available years & 280 & 86 & 194 \\
\hline
\end{tabular}

${ }^{1}$ Figures are the difference between the first figure for the level of central government expenditure that appeared in the IFS within a year after the end of the reported fiscal year and the latest available figure for the same year. Countries that did not have a published figure in the IFS within a year from the end of the fiscal year are excluded. A negative figure indicates that the initial figure was smaller than the final one.

Data cover the years $1960-2000$. 